\title{
リチウムイオン電池の大型化に向けた電池技術の検討
}

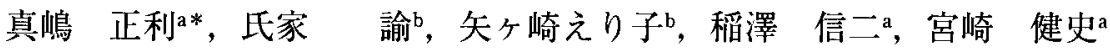 \\ 准友電気工業侏大阪研究所（予554-0024 大阪市此花区島屋 1-1-3） \\ b関西電力侏総合技術研究所（采661-0974 尼崎市若王寺 3-11-20）

\section{Examination on Battery Technology for Scale-up of a Lithium Ion Battery}

\author{
Masatoshi MAJIMA, ${ }^{\text {a }}$ Satoshi UJIIE, ${ }^{\text {b }}$ Eriko YAGASAKI, ${ }^{\text {b }}$ \\ Shinji INAZAWA, ${ }^{\mathrm{a}}$ and Kenji MIYAZAKI ${ }^{\mathrm{a}}$
}

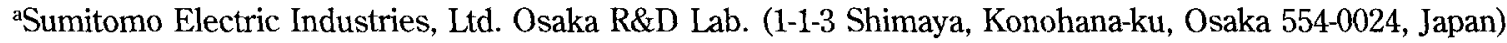

${ }^{\mathrm{b}}$ The Kansai Electric Power Company Inc. Technical Research Center (3-11-20 Nakoji, Amagasaki, Hyogo 661-0974 Japan)
\end{abstract}

Received August 25, 1999 ; Accepted December 7, 1999

\begin{abstract}
To develop battery technology for a large-sized lithium ion battery, particle size of electrode active material, compression of electrodes, drying conditions of electrodes, and electrolyte identities were examined using a coin-cell, and the treatment of the lower edge of electrodes, electrode size, adhesion of electrode active material and current collector, and impregnation condition of electrolytes, were studied using single cells. The followings are particularly important findings obtained in this study. (1) Residual pyrrolidone caused an increase in water content, and thus, drying of electrodes is important in large-sized batteries. (2) Adhesion of electrode active material and current collector can be improved by either increasing the thickness of the current collector or by using an accurate-sized frame during the compression step of electrodes. (3) Both sides of the lower edge of the electrode were covered by precipitates of the Li dendrite during charge-discharge of the battery, and this precipitation was greatly inhibited by applying paste consisting of $75 \%$ natural graphite and $25 \% \mathrm{PVdF}$ at the edge of the anode. (4) Impregnation of electrolytes to large-sized batteries is very difficult compared to that in small ones, since the uniform contact between electrolytes and electrodes requires a longer time. (5) Sealing of the battery case using a viton o-ring can efficiently avoid the mixing of water inside the battery and the evaporation of solvent outside the battery.
\end{abstract}

Key Words : Lithium Ion Battery, Large-scale, Power Storage

\section{1 緒 言}

前報1)で述べたように電力需要家サイドの電力聍蔵電池と して著者らは $1 \mathrm{kWh}$ 級の大型リチウムイオン電池の開発研 究を行っているが, このような研究の進展により長寿命電池 が開発され実用化されるようになれば，電力の頁荷平準化へ の寄与が期待できる点で強い関心がもたれる2).リチウムイ オン電池の電池反忍機構については，これまでにも多くの研 究者により研究され，多数の報告例があるが3-5)，リチウ ムイオン電池の大型化に関する要素技術の報告例は少な (26-7). 特に電極サイズの増大にともなう電池反応の均一 性や電解液の適切な含浸条件など電池の大型化に際して明ら かにしておかなければならない要素技術は決して少なくない.

そこで本研究ではリチウムイオン電池の大型化を目的とし た電池技術に関する検討を行った. すなわち基礎的な材料評 価にはコイン電池を用い, 活物質粒径, 圧縮率, 乾燥条件や 電解液の種類を比較試験した。また電池大型化の基礎検討に は単セルを用い，負極エッジ部の処理，電極サイズ，活物質 と集電体の密着性, 電解液の含浸条件などを比較試験した.
本報告は電池の大型化に際して問題となる検討項目を電極, 電解液, 容器の電池部材ごとに取りまとめたものである。こ れらの問題点の中には必ずしも大型電池でなくても問題とな る項目もあることは当然である。

\section{2 試験方法}

\section{1 電極作製法}

2. 1.1 正極正極活物質としては日本化学工業製の $\mathrm{LiCoO}_{2}$ を，導電助剤しては Lonza 製で平均粒径約 $0.6 \mu \mathrm{m}$ の炭素粉末を，また結着剂としては Aujimont 製の PVdF 粉 末を，さらにペーストを得るための溶剤は双葉化学製の試薬 特級 N-メチル-2-ピロリドンをそれぞれ用いた．正極活物質 は粒径の検討を行った試験以外では，特に断らない限り平均 粒径 $6.5 \mu \mathrm{m}$ のものを用いた。

正極活物質：導電助剂：結着剂：溶剂を重量比で $10: 1$ : $1: 5.5$ の割合で混合し，これを高純度窒素雲团気下で約 1 時 間混練した。得られたペーストはサンク製の電極塗工機によ り, 厚さ約 $20 \mu \mathrm{m}$ のアルミ箔の雨面にドクターブレード法 
で鋈Iした，乾燥条件を検討する際にペーストの塗工条件を 一部変更したが，特に断らない限り，電極乾燥後の集電体を 除く厚みが $270 \mu \mathrm{m}$ ，重量が $0.03 \mathrm{~g} / \mathrm{cm}^{2}$ となるようにペース トの滁工を実施した。電極叙工機ではドクターブレーディン グにより箔に塗られたペーストが直ちに $150^{\circ} \mathrm{C}$ の乾燥雾囲気 を約 2 分間通過するよう設計されており，ここでほとんどの 溶剤を揮散させ，一次乾燥とした。乾燥炉通過後は，電極を 巻き取って恒温槽中に移し， $150^{\circ} \mathrm{C} て ゙ 4$ 日間の真空乾燥（三 次乾燥）により残留溶剤と水分を除去した。一次乾燥後は, 電極圧縮率の検討を実施した試験以外では特に断らない限り， 金属箔の厚みを除いた活物質層の厚みに対して約 $80 \%$ の厚 みとなるよう, サンク製ロールプレス機で電極の圧縮を行っ た。電極を必要なサイズに切り出した後， $150^{\circ} \mathrm{C} て ゙ 4$ 日間の 三次乾燥を常压乾燥法で行い, 電池試作に使用した。

\section{1.2 負極 賁極活物質としては関西熱化学製の天然} 黒鉛を，結着剤としては Aujimont 製の PVdF 粉末を，ペー ストを得るための溶郕は双葉化学製の試薬特級 N-メチルー2ピロリドンをそれぞれ用いた，負極活物質は粒径の検討を行 った試験のように, 特に断らない限り平均粒径 $12.0 \mu \mathrm{m}$ のも のを使用した，負極活物質と結着郕と溶剤を重量比で 10 ： $2: 10$ の割合で混合し，これを高純度窒素雲囲気下で約 1 時 間混練した。得られたペーストはサンク製の電極塗工機によ り，厚さ約 $20 \mu \mathrm{m}$ の銅箔雨面にドクターブレード法で塗工 した。電極厓縮率, 集電体厚み, 乾燥条件掞よびエッジ処理 を検討する際に条件を一部変更したが，その他の場合には， 電極乾燥後の集電体を除く厚みが $280 \mu \mathrm{m}$, 重量が $0.01 \mathrm{~g} /$ $\mathrm{cm}^{2}$ となるようにペーストの染工を実施した，金属箔の厚み を除いた活物質層の厚みに対して約 $60 \%$ の厚みとなるよう 電極の圧縮を行ったことを除くと, 以後の工程は正極と同様 の操作で乾燥および切り出しを行って電池試験に供した。

\section{2 コイン電池の作製}

電極の活物質粒径, 压縮率, 乾燥条件や電解液の種類に関 する比較試験にコイン電池を用いた。コイン電池容器は, 正 極のアルミ製蓋容器, 負極のステンレススチール SUS304 製 の底容器, ニッケル製のスペーサー, 抒よび蓋容器と底容器 を絶縁するためのポリエチレン製ガスケットから成る．正極 は中央部に直径 $1 \mathrm{~mm} の$ 活物質層を取り除いた穴を設け,

この箅所にスポット溶接機で盖容器とアルミ箈学接合して固 定した，なお，電極は门形であり，面積は中央部の穴を除い $て 1 \mathrm{~cm}^{2}$ の面積になるよう設計した．負極は予めニッケルス ペーサーと底容器をスポット溶接で固定した後, 正極同様に して銅䇴とニッケルスペーサーを接合して固定した，電極面 積も正極と同じく $1 \mathrm{~cm}^{2}$ である. 正負極の間に, 厚み 25 $\mu \mathrm{m}$ で正負極より若干大きめのポリプロピレンセパレーター を挿入し,ドライボックス中で電解液を約 $0.2 \mathrm{cc}$ 注液した。 ドライボックスは内部がアルゴン雲团気となっており, 水分 が $0.01 \mathrm{ppm}$ 以下に管理されている. さらに電解液は三菱化 学製で, $1 \mathrm{~mol} \mathrm{dm}^{-3}$ 濃度の $\mathrm{LiPF}_{6}$ を特に断らない限り, エ チレンカーボネート (EC) とジエチルカーボネート （DEC）の体積比で $7: 3$ に混合した溶媒に溶解したものを 用いた。電解液を注液後, ドライボックスに付属するサイド ボックス中で 660 Torr の圧力まで減圧状態にし， 5 分間の 電解液含浸を行った。電解液含浸後, 底容器の上に蓋容器を 重ね,かしめ機で封して電池評価に供した。

\section{3 単セルの作製}

負極エッジ部の处理，電極サイズ，活物質と集電体の密着 性, 電解夜の含浸条件に関する比較試験などには Fig. 1 に示 す単セルを用いた．単セルは正負極を所定のサイズに切り出

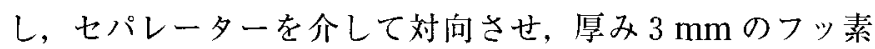
樹脂板で挟み，さらに厚み $10 \mathrm{~mm}$ の SUS304 製の板で外側 から挟んでボルト締めにより固定した。ボルトの本数は電極 サイズにより異なるが, 電極に対して約 $3 \mathrm{~kg} / \mathrm{cm}^{2}$ の圧力が かかるようにトルクレンチにてボルト締めを行った。これを SUS304 製で, 内部がフッ素樹脂コートしてある底容器に抻 入し, 所定量の電解液をドライボックス中で注液後, バイト ン製の○ーリングを介して蓋を閉じ，蓋についている安全弁 の口を利用して，内部を 660 Torr の圧力に減圧し，所定時 間保持した。なお，減压時間は含浸時間の検討を行うまでの 試験では 48 時間で，含浸時間の検討を行った後の試験では 144 時間とした。含浸終了後に蓋を開け, 余剩電解液を除去 した後, 正負極端子と蓋端子を接続して試験電池とした。

\section{4 電池の評価法}

コイン電池㧍よび単セルの電池評価は北斗電工製の $\mathrm{HJ}$ シ リーズ充放䉓装置を用いた。特に断らない限り, 電流密度 $0.4 \mathrm{~mA} / \mathrm{cm}^{2}$ で 4 時間の定電流充電を行い，同電流密度にて $3.0 \mathrm{~V}$ まで放電させるサイクルを繰り返した。な㧍，上限電 圧は $4.2 \mathrm{~V}$ とし, 充電終止電圧の上昇度を基に, 電池の寿命 評価を実施した。

\section{5 セル抵抗の測定}

セル抵抗の測定は定電流密度で充放電させた際の平均充放 電電压を測定し, 式(1)の様に定義した。本研究において平 均電圧は, 30 秒間隔でサンプリングしたデータを基に単純 算術平均にて求めた。

$$
R=\left(V_{\text {charge }}-V_{\text {discharge }}\right) / 2 I
$$

ここで $R$ : セル抵抗, $V_{\text {charge }}$ : 平均充電電压, $V_{\text {discharge }}$ : 平均 放電電圧, $I$ : 充放電時の電流密度である.

\section{3 比較試験結果と検討}

\section{1 電極}

3. 1.1 活物質の粒径 活物質粒径の評価は所定の粒径 の活物質を用い, 活物質量, 電極圧縮率, 電極厚さ, 電解液 は全て 2.1に述べた実験方法に従い共通の条件とした。コ

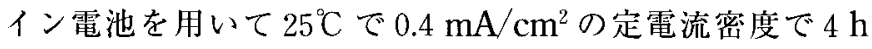
の充電後, $3.0 \mathrm{~V}$ まで放電させるサイクルを繰り返し，この

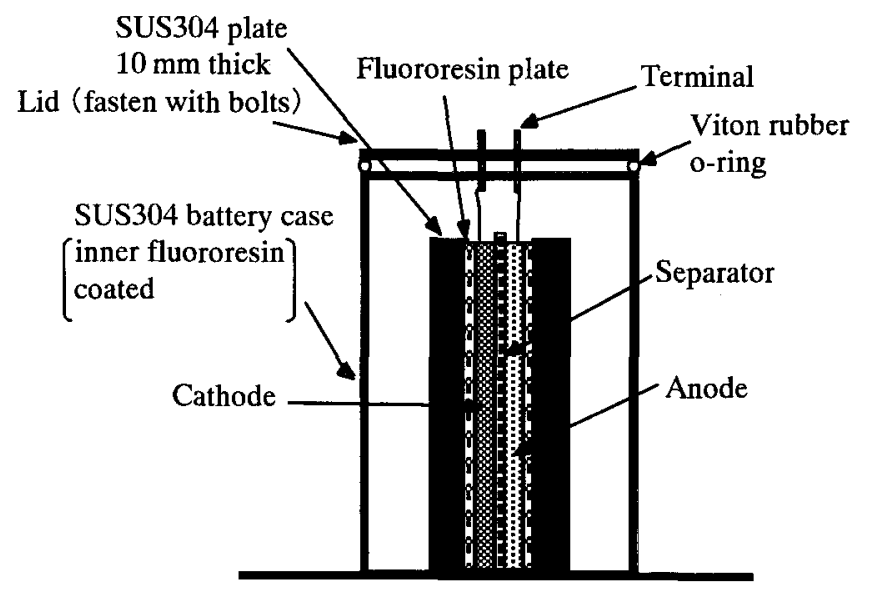

Fig. 1 Schematic illustration of the large-scale single cell lithium ion battery. 
時の充電時の終止電圧を測定した. Fig. 2 は試験結果を示す. 図に示した正極粒径の検討では, 最も小さい平均粒径の 4.5 $\mu \mathrm{m} の も の か ゙ ，$ 初期サイクルでは充電終止電圧が低いが, サ イクルに伴い加速的に劣化が大きくなる結果を得た. 逆に大 きい平均粒径の $10 \mu \mathrm{m} や 20 \mu \mathrm{m}$ のものでは, 初期サイクル より比較的七儿抵抗が大きく，その後小粒径のものに比べる とあるサイクルまではゆるやかでほ注直線的な劣化傾向を示 した.これに対し平均粮径 $6.5 \mu \mathrm{m}$ のものがサイクルに伴う セル抵抗の増加が最も小さいことが判明した，そこで，大型 電池には平均粒径が $6.5 \mu \mathrm{m}$ の活物質を適用することとした。 Fig. 2 の結果は電極活物質の粒径と電極の実効表面積の関係 から説明できる，粒径が小さくなり，実効表面皘が大きくな ると, $\mathrm{Li}^{+}$イオンの出入り口が多くなり，一定電流密度下で は充電終止電圧が下がると考えられる.しかしながら, 粒径 を小さくすることによって悪影響が出てくることも予想され る.すなわち, 活物質が $\mathrm{Li}^{+}$イオンの㨂入・脱離により劣化 する様な場合, 粒径が小なほど劣化のポイントが増すため, 逆に充電終止電圧は上がるというものである. 従って, 活物 質にはある適正な粒径の存在の可能性が示唆される。

一方，負極の天然黒鉛に関しても粒径 6〜20 $\mu \mathrm{m}$ のサンプ ルにて同様の試験を試みたが，正極ほど顕著な差異は認めら れなかったためここでは省略する.

\section{1.2 電極の圧縮率電極圧縮率の評価では活物質量,} 電解液は全て 2.1 に述べた実験方法に従い共通の条件とし

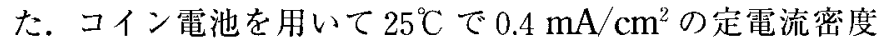
で $4 \mathrm{~h}$ の充電後, $3.0 \mathrm{~V}$ まで放電させるサイクルを繰り返し, この時のセル抵抗を測定して，七ル抵抗に及ぼす压縮率の影 響について検討した，正極王縮率の実験では, 初期活物質層 の厚み $260 \mu \mathrm{m}$ に対して所定の割合で圧縮した電極を用い, この時の負極は活物質層厚みが $200 \mu \mathrm{m}$ のものを用いた．正 極についての試験結果を Fig. 3 に示す，正極の場合，活物質 の圧縮率が小さすぎると, 活物質間の電気的な接触抵抗が大 きく，また逆に压縮しすぎると電解液がしみこむ空間が少な くなりすぎ，七ル抵抗が大になって反応が妨害されることが 推測される，図に明らかなように，正極については圧縮率 $20 \%$ が最適と考えられる。

同椂な測定を負極についても試みた，負極圧縮率の害験で は, 初期活物質層の厚み $280 \mu \mathrm{m}$ に対して所定の割合で压縮 した電極を用い，この時の正極は活物質層厚みが $200 \mu \mathrm{m} の$ ものを用いた．負極の試験結果を Fig. 4 に示す. 負極につい ては圧縮率 40\%が最適であった。これは負極活物質として

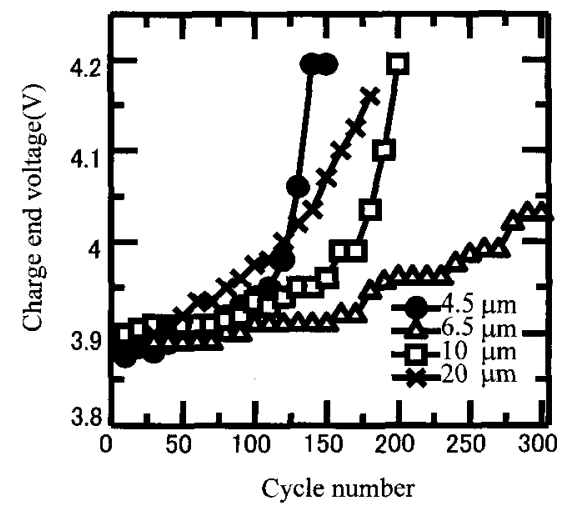

Fig. 2 Effect of the particle size of cathode active material on charge end voltage.

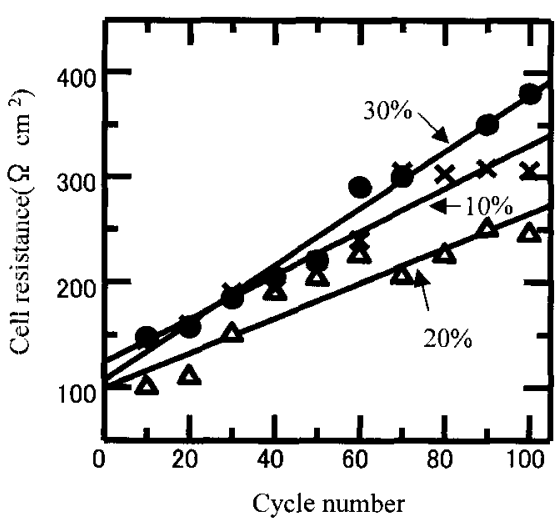

Fig. 3 Effect of bulk modulus of cathode on cell resistancecycle number.

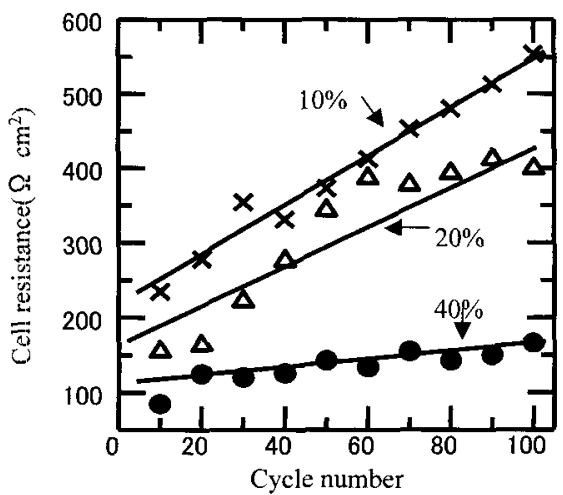

Fig. 4 Effects of bulk modulus of anode on cell resistancecycle number.

用いた天然黑鉛の膨張が正極のそれに比して大であったこと と関連すると考えている。一方，天然黒鉛は鱗片状であるた め圧縮しすぎると粉末が等方的に並んで鏡面光沢を発し， $60 \%$ 圧縮した電杫では充放電が不能となった。

3. 1.3 電極の乾燥条件 大型電池の組立工程で特に留 意しなければならない因子の一つとして水分含量の抑制があ る. 水分は電池寿命に大きな影響を与えると考えられるため, 電極の乾燥について検討した。電極の乾燥は集電体䈃に活物 質合剂を塗工後に行い, 所定温度で $24 \mathrm{~h}$ 真空乾燥した. 電 極調製時の活物質量, 厚み, 圧縮率, および電池に使用した 電解液は 2.1 に示した条件に準じ，コイン電池を用いて $25^{\circ} \mathrm{C}$ で $0.4 \mathrm{~mA} / \mathrm{cm}^{2}$ の定電流密度で $4 \mathrm{~h}$ の充電後, $3.0 \mathrm{~V}$ ま で放電させるサイクルを繰り返した．Fig. 5 は試験結果を示 す。図に明らかなように，乾燥温度が高すぎても，また逆に 低すぎても充電終止電圧は上昇し，電池の長寿命化には不利 である。本試験条件下では $150^{\circ} \mathrm{C}$ が最も低い充電終止電圧を 示す，電極の作製に当たっては，活物質とバインダーを混合 した後ピロリドン溶剤でペースト化し，それを使用している。 水分の除去という観点にたてば，電極乾燥温度が高いほど水 分は蒸発し系外に去って有利と言うことになっうが，電極に 用いるバインダーの融点が $177^{\circ} \mathrm{C} て ゙ あ り ， 170^{\circ} \mathrm{C}$ で乾燥した 場合には部分的な溶融が生起する事が考えられ，これが $170^{\circ} \mathrm{C}$ での充電終止電圧の上昇をもたらしたとも考只られる. 一方, 温度 $142^{\circ} \mathrm{C}$ 前後でペースト中のバインダーの結晶粒径 が最大となり，これが電池寿命に有利に働くという研究報告 もあり ${ }^{8}, 150^{\circ} \mathrm{C}$ 近辺に最適乾燥温度が現れたのであろう。

さらに水のピロリドン溶剤に対する溶解度は極めて大であ ることから，電極中にピロリドンが残留すると，たとえ水分 


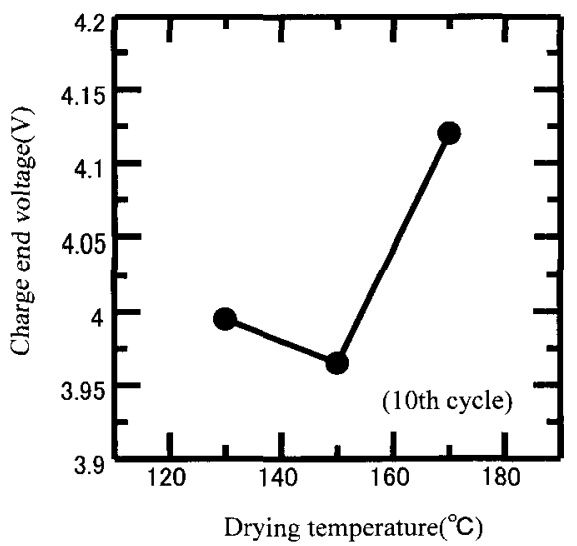

Fig. 5 Effect of drying temperature of electrodes on charge end voltage.

を除去できてもその後の工程で外部からの水分混入量が多く なると考えられる．2.1に示した実験方法に従い $5 \mathrm{~cm}$ 角开

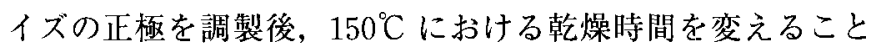
で残留ピロリドン量の異なる 2 水準の正極を準備し，これを $25^{\circ} \mathrm{C}$ ，飽和蒸気压下で所定時間放置して電極の水分増加量を カールフィッシャー法にて求めた. Fig. 6 はこの電極水分量 の経時変化を示したものであり，先の仮説の妥当性を立証す る結果が得られたことになる。

\section{1.4 負極活物質と集電体の接着性がセル抵抗に及ぼす影}

響負極の集電体としては銅䈃を使用しているが，負極 活物質である天然黒鉛とバインダーの混練物の接着性に問題 がある事が第 2 次試作電池の解体の結果明らかになった。接 着性の評価は JIS 規格（K5400）の剥離試験法を基に，交差 角 30 度で $\mathrm{X}$ 型にカッターナイフで電極へ切り迟みを入れ, 切り込み上にスコッチテープを張り付けた後, テープを剥が してその外観を 10 点満点で評価した，接着性は電極圧縮時 の圧縮方法に依存し, さらにこの接着性は充・放電に伴う電 極の膨張・収縮によるセル抵抗の増加と密接な関連を持つと 考えられた。 そこで，銅䈃の厚みを $20 \mu \mathrm{m}$ と $40 \mu \mathrm{m}$ の二段 階に変化させ，他の電極作製条件は2. 1 と同様にして 10 $\mathrm{cm}$ 角の単セルを作製しセル抵抗一サイクル特性を評価した。 なお，本試験における負極の圧縮率は $40 \%$ であり，電池の 試験温度は $25^{\circ} \mathrm{C}$ で $0.4 \mathrm{~mA} / \mathrm{cm}^{2}$ の定電流密度で $4 \mathrm{~h}$ の充電 後 $3.0 \mathrm{~V}$ まで放電させるサイクルを絽り返した．測定結果を Fig. 7 に, 銅箔の厚みを变えた場合の接着性評価結果を Fig. 8 に示す. Fig. 7 に見られるように，銅䇴の厚みを 2 倍

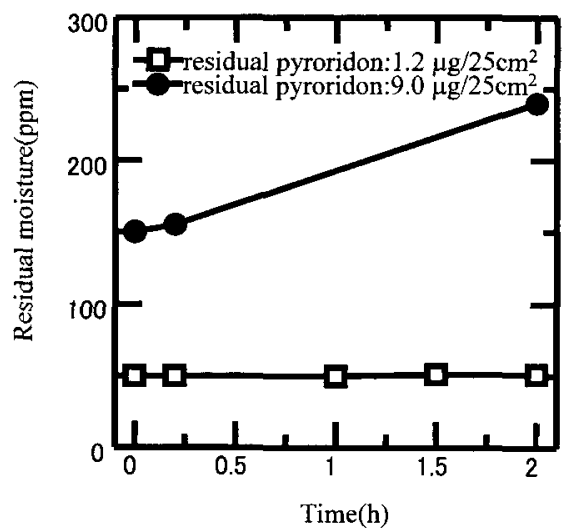

Fig. 6 Time variation of water content in electrodes with different residual pyroridon contents.

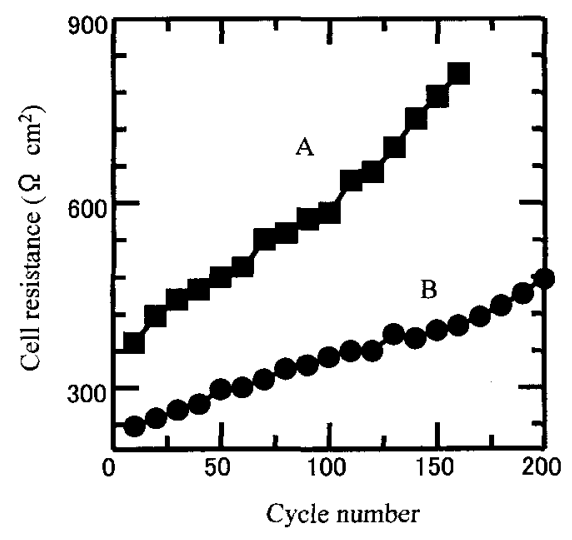

Fig. 7 Effect of thickness of copper foil used as an anode collector on cell resistance. Electrode size : $17 \mathrm{~cm} \times 17 \mathrm{~cm}$, Cu foil thickness : A $20 \mu \mathrm{m}$, B $40 \mu \mathrm{m}$.

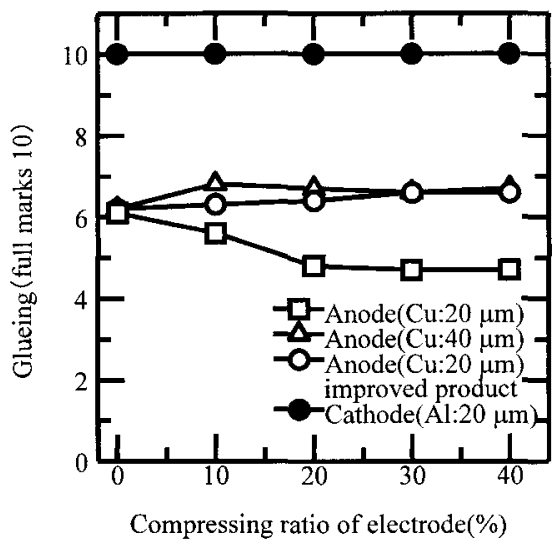

Fig. 8 Effects of bulk modulus on the adhesion of electrode paste on current collector.

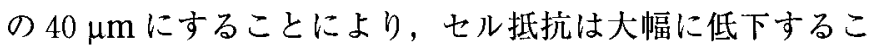
とが分かり，さらにFig. 8 から $40 \mu \mathrm{m}$ 銅䈃適用時には接着 性も向上することが明らかとなった。この知見に基づき，第 3 次試作では負極集電体として, 厚さ $40 \mu \mathrm{m} の$ 銅箔を使用す ることにした，ただし，その後の検討から，接着性の改善は， 応力が発生し難いように厚み $0.5 \mathrm{~mm} の \mathrm{Ti}$ 板で電極を挟み 达むという圧縮工程の改善によっても，Fig.8に示したよう に銅箔厚みを増したと同様の効果が得られた。

3. 1.5 負極エッジ部分の処理 第 2 次および第 3 次試 作電池の解体結果から，負極のエッジ，特に負極の下部特に 下部左右のエッジ部分にはデンドライト状の灰色析出物が異 常に存在していることが分かった ${ }^{1)}$ 。このような Li の異常 析出が観察された原因としては，電極エッジ部に電界が集中 し，均一な反応が阻害されたことが推察される。エッジ部の 電界集中を防ぐためには単位面積当たりの活物質量を減らす ことが有效と考え，負極の下部执よび左右に天然黑鉛 $75 \mathrm{wt}$ \%, PVdF $25 \mathrm{wt} \%$ ペロリドン溶剤を混合して得たバイン ダー混入量の多い活物質ペーストで，幅約 $200 \mu \mathrm{m}$, 厚み約 $100 \mu \mathrm{m}$ 程度に被覆することを試み，他の電極作製条件は 2. 1 と同様にして $10 \mathrm{~cm}$ 角の単セルを作製しセル抵抗一サ イクル特性を評価した。なお，本試験における負極の圧縮率

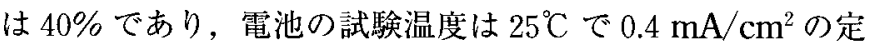
電流密度で $4 \mathrm{~h}$ の充電後 $3.0 \mathrm{~V}$ まで放電させるサイクルを繰 り返した. その結果, Fig. 9 に示すように負極エッジ処理を 


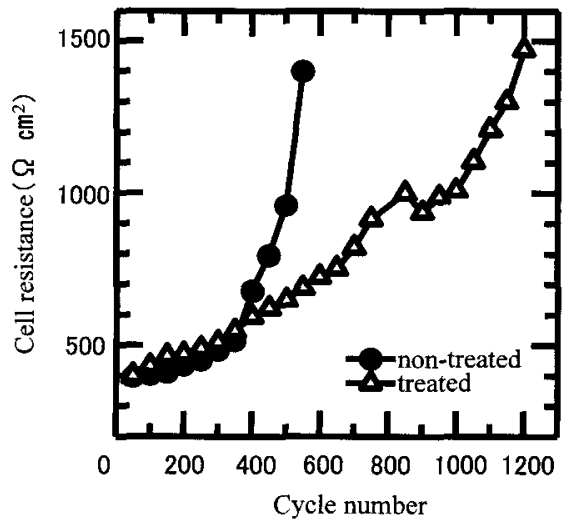

Fig. 9 Effects of edge treatment of the anode on cell resistance.

施した場合には，処理無しの場合に比べてサイクル数の増大 に伴うセル抵抗の増大は遥かに㟌徐になった。

3. 1.6 電極サイズ 充・放電に際しての電極サイズの 影響を調べる目的で, 異なる電極面積の単セルを用いた電池 評価を行った。電極作製条件は2.1 と同様であり，電極に 対して約 $3 \mathrm{~kg} / \mathrm{cm}^{2}$ の圧力がかかるようにして所定サイズの 単セルを作製した。電極タブは上端部に $3 \mathrm{~cm}$ 角の正方形で 取り出し,これをフッ素樹脂被覆導線へボルト留めにより結 線した。電解液は $1 \mathrm{~mol} \mathrm{dm}^{-3} \quad \mathrm{LiPF}_{6}$ の EC/DEC（体積比 $7: 3)$ を用いて 660 Torr, $48 \mathrm{~h}$ の減圧下での含浸を行った。 常圧復帰後, $25^{\circ} \mathrm{C}$ で $0.2 \mathrm{~mA} / \mathrm{cm}^{2}$ の定電流密度にて $8 \mathrm{~h} の$ 充電を行い, $3.0 \mathrm{~V}$ まで放電させるサイクルを繰り返した.

Fig. 10 は 10 サイタル目の充・放電曲線であるが， $14 \mathrm{~cm}$ 角 サイズないし $20 \mathrm{~cm}$ 角サイズの単セルを用いた比較では, 図に明らかなように，電極面積が大きくなるほど充電と放電 の電圧差，すなわち単位面積当たりの抵抗が大きくなること が分かる。

電極サイズの分極への影響は, ‘(1)集電部の電圧降下, (2)電 極活物質層厚みの不均一性, (3)電極に加える外圧の不均一性, (4)電解液含浸量の不均一性などが考えられる. 本試験では, 充放電時の電流密度が $0.2 \mathrm{~mA} / \mathrm{cm}^{2}$ で集電端子部への印加電 流が高々 $80 \mathrm{~mA}$ であり(1)の影響は無視できるレベルである こと,(2)および(3)は異なる電極サイズのセルについて共通の 条件であることを考慮すると，(4)による影響が大きいと推定 された，そこで電解液の含浸条件を 3. 2. 2 に示した様に適 正化することとした.

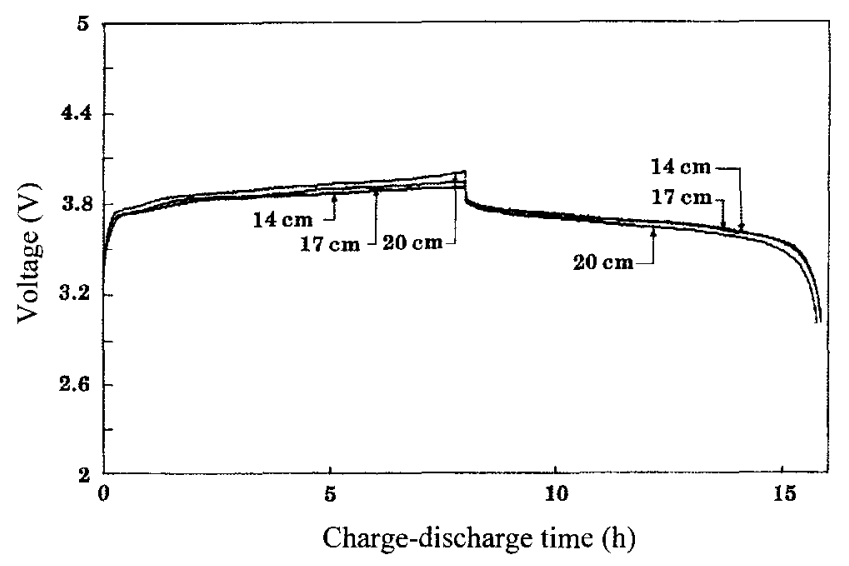

Fig. 10 Influence of electrode size on charge-discharge voltage.

\section{2 電解液}

3. 2.1 電解質の種類ならびに溶媒組成第 1 次試作で

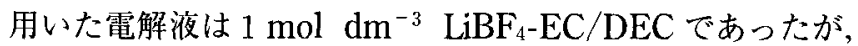
この種の電解液では電流効率が安定するまでに約 20 サイク ルを要し，更に 30 サイクルになっても電流効率は $98 \%$ に到 達したに過ぎない。電解液を $1 \mathrm{~mol} \mathrm{dd^{-3 }} \mathrm{LiPF}_{6}-\mathrm{EC} / \mathrm{DEC}$ に変えたところ，数サイクル後に電流効率は $100 \%$ に達しそ の後も安定した効率を示すことが明らかになった。

電解質濃度は $1 \mathrm{~mol} \mathrm{dm} \mathrm{dm}^{-3}$ とし, それに用いる溶媒として 負極に天然黒鉛を用いた市販電池では ECおよび DEC を混 合して用いることが多い99. EC は誘電率が高く, $\mathrm{LiPF}_{6}$ を $\mathrm{Li}^{+}$と $\mathrm{PF}_{6}$-に解離を起こしやすくする働きがある．EC は常 温では固体であるので，低粘度溶媒であるDECを混ぜて使 用することが必要となる. EC/DECのイオン伝導度は DEC の体積混合率 $50 \%$ が最も高いことが知られており，市販電 池ではこの組成の電解液が採用されることが多い，なるべく 長寿命となるように溶媒組成を適正化するため, $\mathrm{EC} / \mathrm{DEC}$ 割合を変えて充電終止電圧ーサイクル曲線を測定した．電極

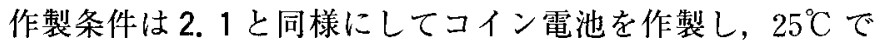
$0.4 \mathrm{~mA} / \mathrm{cm}^{2}$ の定電流密度で $4 \mathrm{~h}$ の充電後 $3.0 \mathrm{~V}$ まで放電さ せるサイクルを繰り返し行い，このときの充電終止電圧を測 定した. Fig. 11 は測定結果を示す.図に明らかなように, 電解液として $1 \mathrm{~mol} \mathrm{dm}{ }^{-3} \mathrm{LiPF}_{6}$ の $\mathrm{EC} / \mathrm{DEC}$ 溶液を用いた 場合には，電池寿命の観点からは DEC 含量 $30 \mathrm{vol} \%$ 最適 であることが分かる．DEC 30 vol\%以下では電解液の粘度 が高くなりすぎるので，この結果を基に第 2 次試作では DEC 30 vol\%の条件を採用した。

3. 2.2 電解液含浸条件の適正化電極寸法については 先に述べた通りであるが, 本研究での測定結果は電極面積の 増大に伴う電解液含浸量の不均一性の存在を示唆したもので あった。そこで, 電極寸法 $17 \mathrm{~cm} \times 17 \mathrm{~cm} の$ 単セル電池を用 いて電解液の含浸を 660 Torr の減圧状態で 24 時間保持した 後, 正極抢よび負極を絴, 横方向にそれぞれ計 9 等分し, 電 解液成分をアセトンで抽出して各部分の Li 量を ICP (Inductively Coupled Plasma）測定で定量分析した。測定結果 はTable 1 に示したように電極の雨下左右端の部分に Li が 比較的多く存在することが分かった。このような $\mathrm{Li} の$ 異常 偏在が観察された原因としては, 電解液の合浸が不完全であ ったことが推察された。

本研究においては, 電解液の含浸は次のように行った。す なわち電極積層体を電池容器に入れた後, 電解液を注入して

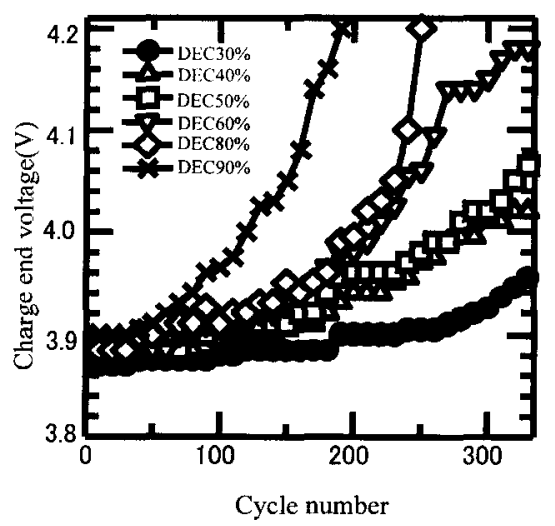

Fig. 11 Effects of mixing ratio DEC in EC/DEC solution on charge end voltage. 
Table 1 Li content in impregnated electrolyte.

\begin{tabular}{clc}
\hline \multicolumn{2}{c}{ Part of the electrodes } & Li content* $(\mu \mathrm{g})$ \\
\hline Upper & right & 35.0 \\
& middle & 37.5 \\
& left & 32.0 \\
\hline \multirow{2}{*}{ Middle } & right & 40.0 \\
& middle & 45.0 \\
& left & 50.0 \\
\hline \multirow{2}{*}{ Lower } & right & 53.5 \\
& middle & 42.5 \\
& left & 50.5 \\
\hline
\end{tabular}

${ }^{*} \mathrm{Li}$ content was analyzed in the impregnated electrolyte after the extraction with acetone.

蓋を閉じ，660 Torr に容器内部を減圧状態にして，24 時間 放置した，仮に電極系への電解液の含浸が不十分であれば， 電極表面において不均質な反応が起こると考えられる。そこ で，電極寸法がそれぞれ $10 \mathrm{~cm} \times 10 \mathrm{~cm}$ および $17 \mathrm{~cm} \times 17$ $\mathrm{cm}$ と異なる 2 種類の単セル電池を組立て，電解液を 660 Torr の弱減圧下で含浸時間を変えて電極系に含浸させ, こ の電池を用いて電流密度 $0.15 \mathrm{~mA} / \mathrm{cm}^{2}$ の定電流条件で充放 電を行い，10 サイクル目のセル抵抗值を測定した。

試験結果を Fig. 12 に示す。電極面積の小さい試料 Bで は，1 時間程度の含浸ですでに，系固有のセル抵抗值に近い 值を示すのに対して，表面積の大きい試料 Aでは含浸時間 の短い間は大きなセル抵抗値を示すが，100 時間の含浸では ほぼ試料 Bのそれに近くなっている。電極面積 $1 \mathrm{~cm}^{2} の コ$ イン電池のセル抵抗をこの電池系の固有セル抵抗であると仮 定し，含浸時間 100 時間における試料 Bのセル抵抗值と試

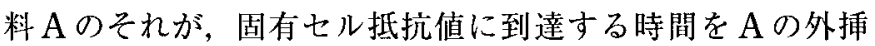
から求めると，144 時問となる.

電極系への電解液の含浸は，含浸を促進するための電池内 圧力の影響を敏感に受けることが考えられる。 そこで，寸法 $17 \mathrm{~cm} \times 17 \mathrm{~cm} の$ 電極の単セルを用いて，含浸時間を 96 時 間の一定とし, 含浸時の圧力を変えて試験を行った。試験結 果を Fig. 13 に示す. 700 Torr から 360 Torrまでの減压条 件下でセル抵抗は減压の程度に伴ってわずかながら減少し， 電池系固有のセル抵抗に近づく。しかし図に明らかなように 300 Torr 以下になると，七ル抵抗は急激に増大寸る。本試 験に用いた電解液は温度 $297 \mathrm{~K}$ において約 300 Torr で沸騰

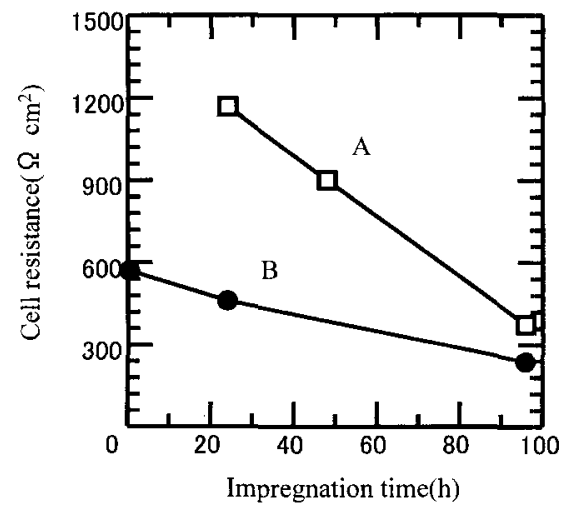

Fig. 12 Effect of impregnation time on cell resistance for the electrode systems using different electrode sizes. (impregnation pressure : 660 Torr) electrode size : A $17 \mathrm{~cm} \times 17$ $\mathrm{cm}$, B $10 \mathrm{~cm} \times 10 \mathrm{~cm}$

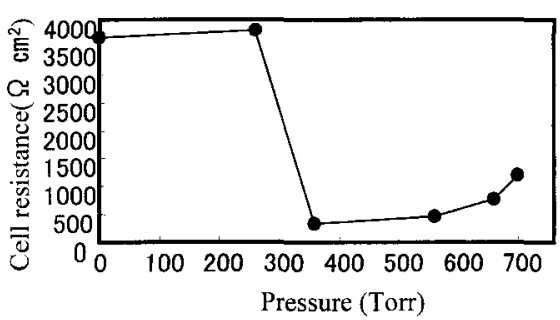

Fig. 13 Effect of impregnation pressure on the cell resistance of a single cell using $17 \mathrm{~cm} \times 17 \mathrm{~cm}$ electrodes. (Impregnation time : $96 \mathrm{hrs}$ )

することが著者らの予備検討で認められており，Fig.13の 結果はこの事実と一致する．強度の減圧下で長時間含浸処置 を行うと電極表面に気泡を生じ，その存在が均一な含浸を阻 害して結果的にセル抵抗の增大に寄与する事も考えられる.

前述の Fig. 12 に示した電極 B では，電極面積はコイン電 池に比べて大きいが，それにも拘わらず含浸開始直後におい てもすでにほぼ系固有のセル抵抗に近い值を示していること から推測して，コイン電池の含浸はほぼ瞬間的に進行するこ とが考えられる。逆に Fig. 12 および Fig. 13 に示した結果か ら分かるように電極寸法が大きくなると，電解液の均一な含 浸は極めて難しい操作であると考えられる。さらにその大型 電極がラミネートされた大型電池では，あまり低すぎない適 当な減圧条件下で，時間を十分長くかけて含浸する事が特に 大切であると考えられる。

\section{3 容器材料および容器の耐シール性}

リチウムイオン電池は容器外部からの混入水分と, 内部の 有機電解液の容器外部への揮散が性能低下に及ぼす影響が大 きいと考えられる。そこで容器のシール性の検討を行うこと とした．直徍 $10 \mathrm{~cm}$, 高さ $10 \mathrm{~cm}$, 厚み $1 \mathrm{~cm} の$ SUS304 製 円筒型の底容器と直径 $10 \mathrm{~cm}$, 厚み $1 \mathrm{~cm}$ の蓋を準備し, 内 部に $1 \mathrm{~mol} \mathrm{dm} \mathrm{dm}^{-3} \mathrm{LiPF}_{6}$ の EC/DEC（体積比 $1: 1$ ）の電解 液を $100 \mathrm{ml}$ 入れた後, 容器と蓋の間のシール材として, (1) バイトンゴム製のO-リング，(2)金属平パッキン，(3)PTFE テープの3 種類をそれぞれ適用し，容器を $60^{\circ} \mathrm{C} ， 20$ 日間飽 和蒸気圧下で放置した。放置後, 電解液中の水分量と EC/ DEC 組成比率を測定した。その結果，Fig. 14 に示したよう

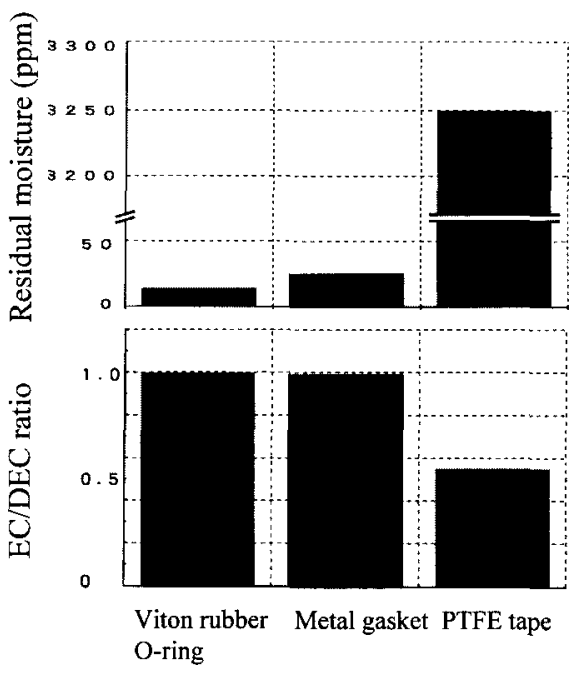

Fig. 14 Effects of sealing agent used on residual moisture and $\mathrm{EC} / \mathrm{DEC}$ ratio in the battery. 
に(1)のバイトンOーリングが水分および電解液の遮断性に優 れることが分かったため，(1)を適用することとした。

\section{4 結 言}

リチウムイオン電池の大型化に向けた電池技術の開発を目 的として, 活物質粒徍, 圧縮率, 電極乾燥条件や電解液の種 類の比較検討にはコイン電池を, また負極エッジ部の処理, 電極サイズ, 活物質と集電体の接着性, 電解液含浸条件など の大型化の検討には単セルを用いて試験を行い, 適正值なら びに適正条件の決定を行った，得られた主な知見は次の通り である。

1. 電極

（1） $\mathrm{LiCoO}_{2}$ を正極活物質として用いた場合の適正粒径は 6.5 $\mu \mathrm{m}$ であるのに対し，負極活物質として用いた天然黒鉛 では充電終止電圧に及ぼす粒子径の影響は小さい。

（2）適正電極圧縮率として正極 20\%，負極 $40 \%$ の値を見出 した。

（3）電極の乾燥温度は $150^{\circ} \mathrm{C}$ が適当である. 電極中の残留ピ ロリドンは乾燥工程後の水分混入を導くため, 極力排除 することが重要である.

（4）活物質と集電体の接着性はセル抵抗に影響を及ぼすが, この影響を小さくする為には負極集電体として用いた銅 箔の厚さを增す, 或いは応力発生防止用の板材で圧縮時 に電極を挟み込んでもよい.

（5）負極の特に下方のエッジ部に析出する $\mathrm{Li}$ デンドライト

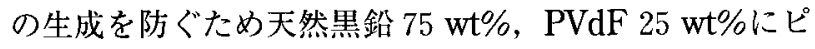
ロリドンを混合した活物質ペーストを塗布することが有 効である。

（6）電極面積を大きくするほど単位面積当たりの抵抗が大に なり，これは電解液含浸量の不均一性に影響されること が大である。

2. 電解液

（1） EC/DECに溶解調整した $1 \mathrm{~mol} \mathrm{dm}^{-3} \mathrm{LiPF}_{6}$ を電解質
として用いた電解液では EC：DECの適正体積比は 7： 3であった。

（2）大型リチウムイオン電池に対する電解液の含浸は小型の それより困難である。均一に電解液を含浸させるための 適正条件として含浸圧 360 Torr で含浸時間 $144 \mathrm{~h}$ が必 要である。

3. 電池容器の耐シール性

電池容器の外部からの水分混入防止と有機溶媒の容器外 部への揮発を抑制するにはバイトンOーリングが優れてい る.

\section{文献}

1）真嶋正利，氏家 諭，矢ヶ崎えり子，稲澤信二，宮崎健史， Electrochemistry, 68, 174 (2000).

2）田中祀捷, 岩堀 徹, 熊并一馬, 寺田信之, 横田 勤, 石原 薰, 竹井勝二, 池谷知彦, ロードコンディショナーの開 発, $10 \mathrm{kWh}$ 級ロードコンディショナーの可能性, 電力中央 研究所報告, 総合報告 T16 (1990).

3) T. Ohzuku, A. Ueda, and M. Nagayama, J. Electrochem. Soc., 140, 1862 (1993).

4) J. R. Dahn, U. von Sacken, and C. A. Michal, Solid State Ionics, 44, 87 (1994).

5) J. N. Reimers and J. R. Dahn, J. Electrochem. Soc., 139, 2091 (1992).

6) M. Majima, K. Hanafusa, Y. Oka, G. Tanaka, H. Yoshida, E. Yagasaki, and T. Tada, J. Power Sources, 68, 448 (1997).

7) M. Majima, S. Ujiie, E. Yagasaki, S. Inazawa, and K. Miyazaki, J. Power Sources, 81-82, 877 (1999).

8) S. T. Mayer, H. C. Yoon, C. Bragg, and J. H. Lee, 13 th Int. Semin. Prim. Second Battery Technol., Appl, 247 (1996).

9）菅原秀一，電池技術と材料 - 周辺技術，電気化学セミナ ,$- 71(1996)$. 